\title{
QUANTIFICAÇÃO DA MICROPROPAGAÇÃO DE Curcuma zedoaria ROSCOE
}

\author{
Marcia O. Mello; Antônio F. C. Amaral; Murilo Melo* \\ Depto. de Ciências Biológicas - CEBTEC/USP/ESALQ - CEP:13.418-900 - Piracicaba, SP. \\ *Autor correspondente <mmelo@carpa.ciagri.usp.br>
}

RESUMO: Curcuma zedoaria Roscoe, planta pertencente à família Zingiberaceae que se propaga vegetativamente, tem sido utilizada amplamente por suas propriedades terapêuticas. $O$ interesse na propagação em massa de plantas medicinais in vitro tem aumentado sensivelmente, pois os métodos convencionais de propagação limitam o potencial de utilização destas plantas. Ápices caulinares foram inoculados em meio de cultura sólido contendo os sais básicos e vitaminas de Murashige \& Skoog, suplementado com 2,0 mg L $\mathrm{L}^{-1} \mathrm{de}$ BAP e $30 \mathrm{~g} \mathrm{~L}^{-1}$ de sacarose. As culturas foram incubadas em sala de crescimento a temperatura de $25 \pm 2^{\circ} \mathrm{C}$ com fotoperíodo de 16/8 horas de claro/escuro. Transferências e repicagens foram realizadas a cada 40 dias. Os resultados das avaliações feitas permitiram determinar o número de plantas obtidas em cada repicagem e estimar o número de plantas possíveis de serem obtidas após qualquer número de repicagens a partir de 120 dias da inoculação, com base na equação matemática $y=8,74 x^{2}-21,19 x+23,47$, onde y é o número de plantas produzidas e x o número de repicagens a serem realizadas, a partir de um explante. $\mathrm{O}$ custo da muda considerando-se a produção de 200.000 mudas/ano foi de $\mathrm{R} \$ 0,70$.

Palavras-chave: zedoaria, cultura de tecido, produção, muda

\section{QUANTIFYING THE MICROPROPAGATION OF Curcuma zedoaria ROSCOE}

\begin{abstract}
Curcuma zedoaria Roscoe, a vegetatively propagated member of the Zingiberaceae family, has been used extensively due to therapeutic properties. The interest of in vitro massal propagation of medicinal plants has improved since the conventional methods of propagation limit the utilization potential of these plants. Shoot meristems were inoculated on agar-solidified culture media containing the basic salts and vitamins of Murashige \& Skoog supplemented with $2.0 \mathrm{mg} \mathrm{L}^{-1}$ BAP and $30 \mathrm{~g} \mathrm{~L}^{-1}$ sucrose. The cultures were incubated in a growth room at $25 \pm 2^{\circ} \mathrm{C}$ and $16 / 8$ hours photoperiod (light/dark). Transfers were carried out each 40 days. The results obtained allowed the determination of the number of plants produced by each transfer. It was also possible to estimate the number of plants to be produced at any number of transfers after 120 days from inoculation, based on the following equation: $y=8.74 x^{2}-21.19 x+23.47$, where $y$ is the number of plants produced and $\mathrm{x}$ is the number of transfers to be perfomed from each explant. The cost of $C$. zedoaria plants produced in vitro was US $\$ 0.38 /$ plant when a production of 200,000 plants/year is considered.
\end{abstract}

Key words: zedoaria, tissue culture, plant production

\section{INTRODUÇÃO}

Curcuma zedoaria Roscoe, pertencente à família Zingiberaceae, é planta herbácea aromática provida de rizoma rico em óleo essencial (Guenther, 1952) o qual apresenta propriedades terapêuticas atualmente exploradas comercialmente. Esta planta é bastante conhecida na medicina popular e tradicional, sendo utilizada como expectorante, demulcente, diurético, rubefaciente, estimulante do processo de digestão, colagogo e no tratamento da gastrite (Maeda, 1984; Miyake, 1986; Yasuda et al., 1988). Atualmente, destaca-se também sua potencialidade como anti inflamatório, graças ao seu efeito anti-oxidante (Yoshioka et al., 1998), e no tratamento de câncer (Syu et al., 1998). Sua propagação é feita vegetativamente através do plantio de fragmentos de rizoma. Entretanto a dificuldade de armazenamento dos rizomas utilizados como "sementes", os problemas fitossanitários (Yasuda et al., 1988), a dormência das gemas ao longo de estações com dias curtos e frios e o aumento na demanda por matéria-prima para a produção de medicamentos e corantes industriais obtidos à partir do rizoma desta planta fazem com que a propagação vegetativa convencional para a multiplicação em larga escala seja ineficiente e não atenda a crescente demanda do mercado consumidor.

O cultivo in vitro aparece como uma alternativa que supera tais dificuldades e já tem se mostrado uma opção viável para outros membros da família Zingiberaceae como Curcuma domestica (Dekkers et al., 1991), Zingiber officinale (Vicent et al., 1992) e Alpinia purpurata (Illg \& Faria, 1995). Estas técnicas de cultivo in vitro apresentam grande eficiência favorecendo a rápida multiplicação e produção de zingiberáceas em quantidade e qualidade superiores àquelas obtidas através de métodos convencionais (Tavares et al., 1992), contornando problemas sérios como a dormência dos rizomas durante 0 período do inverno e transmissão de doenças comuns em sistemas de propagação vegetativa . Além disto, tal técnica vem se mostrando economicamente superior à produção de mudas convencionais, como no caso da banana, onde a muda 
produzida in vitro é cerca de $70 \%$ mais barata do que a muda produzida em campo através da propagação vegetativa convencional, segundo informação de produtores agrícolas (Crocomo, 1999)'.

Sendo C. zedoaria uma planta propagada vegetativamente, esta propagação nem sempre é acompanhada por variações genéticas como normalmente ocorre nas plantas propagadas por sementes. Neste contexto, uma outra vantagem do cultivo in vitro é a possibilidade de se explorar variações somaclonais que possam surgir em tais condições para o melhoramento da cultura (Silvarolla, 1992).

Tendo em vista a importância crescente da cultura e as dificuldades envolvidas em seu processo de produção a campo, o objetivo do presente trabalho foi o de desenvolver um método eficiente de micropropagação planejado e estruturado para ser empregado em escala comercial de produção de mudas de C. zedoaria.

\section{MATERIAL E MÉTODOS}

Rizomas de C. zedoaria para extração de explantes foram coletados ao acaso nos galpões de processamento de rizomas de produtores da região de Santo Amaro (SP). Depois de coletados, estes foram lavados em água corrente para remoção de partículas de solo e colocados para germinar em bandejas com vermiculita autoclavada em casa de vegetação.

Os brotos laterais formados foram destacados do rizoma e lavados em água corrente. Após limpeza superficial para remoção de detritos, os brotos foram mergulhados em solução comercial de hipoclorito de sódio (Q-Boa) a $20 \%\left(v v^{-1}\right)$ por 5 minutos, seguindo-se da remoção das folhas mais externas e da extremidade superior dos brotos. As partes basais dos brotos contendo o ápice foram então levadas para câmara asséptica e transferidas para solução comercial de hipoclorito de sódio (Q-Boa) a 20\% $\left(v v^{-1}\right)+$ Tween a $0,1 \%\left(v v^{-1}\right)$ e deixadas sob agitação constante por 20 minutos. Em seguida foram lavadas 3 vezes com água destilada esterilizada.

Com o auxílio de lupa, pinça, bisturi e estilete, o ápice foi isolado e inoculado em meio de cultura contendo os sais básicos e vitaminas de Murashige \& Skoog (1962), suplementado com 2,0 $\mathrm{mg} \mathrm{L}^{-1}$ de BAP (benzilaminopurina) e $30 \mathrm{~g} \mathrm{~L}^{-1}$ de sacarose, solidificado com $8,0 \mathrm{~g} \mathrm{~L}^{-1}$ de Ágar sendo o pH ajustado a $5.8 \mathrm{com} 0,1 \mathrm{M} \mathrm{KOH}$ antes da autoclavagem a $120^{\circ} \mathrm{C}$ por 30 minutos.

As culturas foram mantidas em sala de crescimento a $25 \pm 2^{\circ} \mathrm{C}$ sob condições de fotoperíodo de $16 / 8$ horas de claro/ escuro, providas por lâmpadas fluorescentes brancas (General Electric-40W de $31 \mu \mathrm{mol} \mathrm{m} \mathrm{m}^{-2} \mathrm{~s}^{-1}$ ).

Foram inoculados 15 ápices caulinares, cada um constituindo uma repetição. Repicagens foram realizadas a cada 40 dias, quando eram contados 0 número de brotos originados de cada explante. Foram realizadas 5 repicagens, aos 120, 160, 200, 240 e 280 dias após a inoculação, embora os explantes tenham sido transferidos para novo meio de cultura aos 40 e 80 dias após a inoculação. Na última repicagem (280 dias) as plantas foram transferidas diretamente para 0 substrato para serem aclimatizadas.

Os resultados foram analisados estatisticamente e uma equação matemática foi determinada a qual permite estimar o número de plantas possíveis de serem obtidas após qualquer número de repicagens (após 120 dias da inoculação) a partir de um explante, viabilizando o planejamento de produção de mudas utilizando estas técnicas em escala comercial.

O cálculo dos custos envolvidos na produção de mudas em cultura de tecidos de $C$. zedoaria envolveu a taxa de multiplicação da planta in vitro e os custos da infraestrutura de um laboratório. Neste caso foi considerado a estrutura necessária para a produção de 200 mil mudas por ano e no máximo seis transferências para se evitar a incidência de variação somaclonal. Todos os custos foram baseados nos dados de Oliveira (1998) e amortizados segundo Anderson \& Meagher (1977). Os juros aqui utilizados para fins de cálculo foram de $15 \%$ ao ano e o laboratório estaria trabalhando na produção de diferentes tipos de mudas ao mesmo tempo para que a estrutura não permanecesse ociosa durante alguns períodos do ano.

Para a execução deste trabalho foi utilizado um laboratório de micropropagação dividido em sala de preparo de meio de cultura $\left(35 \mathrm{~m}^{2}\right)$, sala de autoclavagem $\left(16 \mathrm{~m}^{2}\right)$, sala de repicagem $\left(20 \mathrm{~m}^{2}\right)$, sala de crescimento $\left(24 \mathrm{~m}^{2}\right)$, almoxarifado $\left(10 \mathrm{~m}^{2}\right)$ e escritório $\left(15 \mathrm{~m}^{2}\right)$ sendo o custo $\mathrm{m}^{-2}$ de $\mathrm{R} \$ 250,00$, amortizado em 20 anos. Também foram considerados um barracão de $70 \mathrm{~m}^{2}$ com custo $\mathrm{m}^{-2}$ de $\mathrm{R} \$ 70,00$ e uma casa de vegetação de $250 \mathrm{~m}^{2}$ com custo $\mathrm{m}^{-2}$ de $R \$ 150,00$, que tiveram seus custos amortizados em 10 anos. Os equipamentos de laboratório necessários para atingir os objetivos são: agitador orbital magnético (2), aparelhos de ar condicionado 30.000 BTU (4), autoclave $70 \mathrm{~L}$ (2), balança de precisão (1), balança técnica (1), câmara de fluxo laminar horizontal (4), deionizador $10 \mathrm{~L} \mathrm{~h}^{-1}$ (1), destilador $10 \mathrm{~L} \mathrm{~h}^{-1}$ (1), exaustor (1), geladeira com freezer (1), e pHmetro (1), sendo o valor de cada equipamento avaliado segundo preço de mercado e amortizado em 5 anos. $\mathrm{O}$ custo de material permanente e semi-permanente de consumo como mobiliário, lâmpadas, vidraria, material plástico, bisturis e pinças, tiveram seus custos amortizados em 2 anos. $O$ custo do meio de cultura foi baseado no preço FOB apresentado pela Sigma (1999) mais as taxas alfandegárias e de transporte. A mão-de-obra necessária estimada foi de um supervisor, um preparador de meio, dois auxiliares e quatro repicadores.

Com relação aos gastos com energia elétrica, foi considerado que o consumo com salas de crescimento e repicagem corresponde a aproximadamente $70 \%$ do consumo total do laboratório. Outras dependências consomem os outros $30 \%$. Conforme recomendação do "Engineering Bulletin 0-285" (Sylvania, s.d.) para a iluminação de casas de vegetação e salas de crescimento, 
o consumo é de $215 \mathrm{w} \mathrm{m}^{-2}$. Para a manutenção da temperatura nas dependências do laboratório foram considerados 4 aparelhos de ar condicionados ligados 2 a 2 alternadamente, os quais consomem $2.500 \mathrm{w} \mathrm{h}^{-1}$. Os gastos com água foram calculados assumindo que a maior parte do consumo $(70 \%)$ está relacionado à lavagem de vidrarias e os outros 30\% à irrigação e manutenção das instalações. Para a lavagem das vidrarias foi estimado 0 consumo de 1,0 litro de água por vidro.

\section{RESULTADOS E DISCUSSÃO}

A micropropagação in vitro de C. zedoaria utilizando inoculação de ápices em meio MS suplementado com 2,0 mg L-1 BAP é técnica economicamente viável.

A TABELA 1 mostra os dados obtidos durante a condução do experimento (320 dias) para as 10 repetições (excluídas as perdas iniciais) utilizadas para os cálculos.

A contagem dos brotos iniciou-se 120 dias após a inoculação dos ápices caulinares no meio de cultura (primeira repicagem). Isto se deve ao fato de que apenas brotações iguais ou maiores que $0,5 \mathrm{~cm}$ foram contadas. Após 40 dias podia-se perceber a hipertrofia do explante e o início da diferenciação das gemas que ficou mais evidente após 80 dias. Porém nesta fase nenhum dos brotos havia atingido um tamanho superior a $0,5 \mathrm{~cm}$ não sendo portanto considerados nos cálculos para a determinação da equação. Depois de diferenciadas as gemas apresentavam rápido crescimento e desenvolvimento da parte aérea e do sistema radicular.

Aos 280 dias, todas as plantas maiores que 4,0 $\mathrm{cm}$ obtidas in vitro foram avaliadas e transferidas para bandejas contendo areia autoclavada para a aclimatação em casa de vegetação. Estas plantas apresentavam sistema radicular bem desenvolvido e puderam ser aclimatizadas com sucesso (avaliação feita aos 320 dias), sendo as perdas nesta fase nunca superiores a $5 \%$ quando uma

TABELA1 - Quantificação do número de mudas (brotos/ápice inoculado) obtido nas repicagens realizadas $(120,160,200,240$ e 280 dias) durante a micropropagação in vitro de C. zedoaria.

\begin{tabular}{cccccccc}
\hline \multicolumn{8}{c}{ Repicagens } \\
\hline & 0 & 1 & 2 & 3 & 4 & 5 & $\begin{array}{c}\text { Total de plantas } \\
\text { aclimatizadas }\end{array}$ \\
\hline Repetição & 120 & 160 & 200 & 240 & 280 & 320 & Dias \\
\hline 1 & 1 & 8 & 16 & 24 & 56 & 91 & 86 \\
2 & 1 & 13 & 25 & 45 & 76 & 71 & 67 \\
3 & 1 & 14 & 26 & 64 & 141 & 273 & 259 \\
4 & 1 & 15 & 22 & 40 & 76 & 193 & 183 \\
5 & 1 & 5 & 14 & 30 & 48 & 68 & 65 \\
6 & 1 & 5 & 6 & 23 & 41 & 70 & 67 \\
7 & 1 & 5 & 11 & 22 & 35 & 57 & 54 \\
8 & 1 & 9 & 15 & 33 & 46 & 85 & 81 \\
9 & 1 & 9 & 36 & 66 & 132 & 281 & 267 \\
10 & 1 & 8 & 25 & 47 & 88 & 193 & 183 \\
\hline
\end{tabular}

cobertura plástica era mantida sobre as bandejas para assegurar alta umidade relativa do ambiente por 20 dias. Taxas de sobrevivência de $95 \%$ se comparam aquelas mais elevadas obtidas por Dekkers et al. (1991) com gengibre.

As perdas obtidas no momento da inoculação foram de $33 \%$, sendo estas constituídas parte por contaminação por fungos e parte por falhas no isolamento do meristema apical que se oxidava e não se desenvolvia. Assim, uma maior destreza no isolamento dos ápices e a adoção de uma assepsia superficial mais efetiva, com emprego de uma maior concentração do agente esterilizante, maior período de tratamento ou utilização de outro composto desinfestante para o procedimento (Tavares et al., 1992) podem reduzir para níveis mais baixos as perdas aqui ocorridas. Nesta fase inicial de introdução do material in vitro foi onde ocorreram as maiores perdas de todo 0 processo, sendo que perdas durante o cultivo in vitro podem ser consideradas inexistentes.

As plantas originadas da micropropagação se desenvolveram bem em casa de vegetação, alcançaram tamanho normal e produziram rizomas que foram utilizados como "sementes" e germinaram dando origem a plantas normais nos segundo e terceiro ciclos (segundo e terceiro anos) de cultivo ex vitro. Estes resultados reafirmam a viabilidade do método empregado.

Segundo análise estatística dos dados, a equação matemática que representa a produção de plantas de $C$. zedoaria pela técnica de micropropagação in vitro pode ser representada por $y=8,74 x^{2}-21,19 x+23,47$, onde $y$ representa a produção em número de plantas e $\mathrm{x}$ o número de repicagens necessárias para a produção de y plantas a partir de um explante. É importante ressaltar que número de repicagens superior a seis não é recomendado para se evitar a incidência de variação somaclonal, ou seja, mudanças nas características do material produzido devido ao longo cultivo in vitro.

A Figura 1 mostra a dispersão dos dados apresentados na TABELA 1 e a linha que representa a evolução do número de plantas obtidas no decorrer do experimento. Na equação matemática obtida, 0 valor $\mathrm{x}=$ 1 corresponde à primeira repicagem na qual foi possível contar o número de brotos (após 120 dias) e valores de $\mathrm{x}$ $=2,3,4 \ldots$ correspondem às outras transferências realizadas em intervalos de 40 dias.

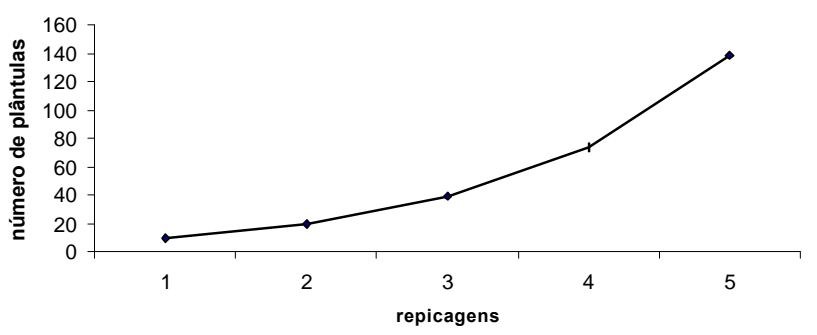

Figura 1 - Quantificação da micropropagação de C. zedoaria (plantas/ápice inoculado) em meio MS + 2,0 $\mathrm{g} \mathrm{L}^{-1} \mathrm{BAP}$, com a realização de transferências periódicas a cada 40 dias. 
TABELA 2 - Quantificação dos custos de produção de mudas de C. zedoaria por micropropagação in vitro.

\begin{tabular}{lccc}
\hline Componente & Custo total & Tempo de amortização & Custo amortizado/ano \\
\hline & $\mathrm{R} \$$ & anos & $\mathrm{R} \$$ ano $^{-1}$ \\
Laboratório $\left(120 \mathrm{~m}^{2}\right)$ & $30.000,00$ & 20 & $4.471,00$ \\
Barracão $\left(70 \mathrm{~m}^{2}\right)$ & $4.900,00$ & 10 & 912,00 \\
Casa-de-vegetação $\left(250 \mathrm{~m}^{2}\right)$ & $37.500,00$ & 10 & $6.978,00$ \\
Equipamentos & $33.560,00$ & 5 & $9.367,00$ \\
Material permanente e semi-permanente & $21.500,00$ & 2 & $12.373,00$ \\
Meio de cultura & $31.500,00$ & -- & $31.500,00$ \\
Mão-de-obra & $64.800,00$ & -- & $64.800,00$ \\
Água* & 217,00 & -- & 217,00 \\
Eletricidade* & $14.151,00$ & -- & $14.151,00$ \\
\hline TOTAL & & & $140.359,00$
\end{tabular}

*são componentes de custo que dependem de como os laboratórios manipulam e da região considerada.

Os resultados obtidos no presente trabalho indicam que a cada repicagem ou 40 dias de cultura, 0 número de plantas obtidas praticamente dobrava, um nível semelhante ao obtido em Alpinia purpurata (Tavares et al., 1992; Chang \& Criley, 1993) e em Curcuma amada e Curcuma domestica (Dekkers et al., 1991), porém inferior ao obtido em Zingiber officinale (Bhagyalakshmi \& Singh, 1988), em Kaempferia galanga (Vicent et al., 1992) e em Alpinia purpurata (Illg \& Faria, 1995), todas membros da família Zingiberaceae.

A manutenção destas plantas com baixo crescimento vegetativo in vitro foi obtida cultivando-se as plantas em meio de cultura sólido contendo metade da concentração dos sais básicos e vitaminas de Murashige \& Skoog (1962), suplementado com $30 \mathrm{~g} \mathrm{~L}^{-1}$ de sacarose. Estas culturas foram mantidas sob as mesmas condições de temperatura e fotoperíodo descritas para a micropropagação. As transferências eram realizadas periodicamente a cada 60 dias e sob estas condições, as plantas foram mantidas por 2 anos sendo que a cada transferência era realizada a eliminação de todas as raízes e das folhas mais velhas. Este procedimento visa estabelecer protocolo de micropropagação ajustado a variáveis demandas de mudas.

O cálculo dos custos envolvidos na produção comercial de mudas de $C$. zedoaria, baseados nos dados de Oliveira (1998) e Anderson \& Meagher (1977) (TABELA 2) mostra que o preço da muda produzida in vitro é cerca de $\mathrm{R} \$ 0,70$ a muda. A qualidade das mudas produzidas in vitro, considerando a homogeneidade e características fitossanitárias, é superior àquela das mudas produzidas de modo convencional. Além disto, é possível obter quantidades que atendam de modo satisfatório a demanda do mercado.

\section{CONCLUSÕES}

A produção controlada e programada de mudas de Curcuma zedoaria Roacoe in vitro é viável utilizando cultura de ápices caulinares. A quantificação da produtividade e dos custos do protocolo de micropropagação permitiram o estabelecimento de equação matemática que possibilita a programação no procedimento e o custo das mudas obtidas que foi de $\mathrm{R} \$ 0,70$ por muda. Programação do processo que permite ajustar-se à demanda, homogeneidade e qualidade fitossanitária das mudas obtidas são os destaques dos resultados alcançados neste trabalho.

\section{AGRADECIMENTOS}

À Fundação de Amparo à Pesquisa do Estado de São Paulo (FAPESP) pelo auxílio financeiro e ao professor Dr. Décio Barbin pelo auxílio nas análises estatísticas.

\section{REFERÊNCIAS BIBLIOGRÁFICAS}

ANDERSON, W.C.; MEAGHER, G.W. Cost of propagating broccoli plants through tissue culture. HortScience, v.12, p.543-544, 1977.

BHAGYALAKSHMI; SINGH, N.S. Meristem culture and micropropagation of a variety of ginger with a high yield of oleoresin. Journal of Horticultural Science, v.63, p.321-327, 1988.

CHANG, B.K.W.; CRILEY, R.A. Clonal propagation of pink ginger in vitro. HortScience, v.28, p.1203, 1993.

DEKKERS, A.J.; RAO, A.N.; GOH, C.J. In vitro storage of multiple shoot cultures of gingers at ambient temperature of $24-29^{\circ} \mathrm{C}$. Scientia Horticulturae, v.47, p.157-167, 1991.

GUENTHER, E. The essential oils. Toronto: D. Van Nostrand, 1952. 342p.

ILLG, R.D.; FARIA, R.T. Micropropagation of Alpinia purpurata from inflorescence buds. Plant Cell, Tissue and Organ Culture, v.40, p.183-185, 1995.

MAEDA, H. Pharmacological effects of the powder from Curcuma zedoaria Roscoe on the gastrointestinal tract of experimental animals. Yakugaku Zasshi, v.104, p.640-643, 1984.

MIYAKE, E.T. Zedoaria. Revista Brasileira de Farmacologia, v.1, p.192-199, 1986.

MURASHIGE, T.; SKOOG, F. A revised medium for rapid growth and bioassays with tobacco tissue cultures. Physiologia Plantarum, v.15, p.473-497, 1962.

OLIVEIRA, R.P. Infra-estrutura e custos de um laboratório de produção de mudas de bananeira. Cruz das Almas: EMBRAPA, 1998.17p. 
SILVAROLLA, M.B. Plant genomic alterations due to tissue culture. Journal of Brazilian Association of Advance Science, v.44, p.329-335, 1992.

SYLVANIA. Gro-lux wide spectrum fluorescent lamp - Sylvania's plant growth lamp for hastening plant growth and flowering. Danvers: Sylvania Lighting Center, s.d. 8p. (Engineering Bulletin 0-285).

SYU, W.J.; SHEN, C.C.; DON, M.J.; OU, J.C.; LEE, G.H.; SUN, C.M. Cytotoxicity of curcuminoids and some novel compounds from Curcuma zedoaria. Journal of Natural Products, v.61, p.15311534, 1998.

TAVARES,A.R.; CASTRO, C.E.F.; COSTA, A.M.M. Propagação in vitro de Alpinia purpurata (Vieill) K. Schum. In: CONGRESSO DA Sociedade de Botânica de São Paulo, 8., Campinas, 1990. Anais. São Paulo: SBSP, 1992. p.67-69.
VICENT, K.A.; MATHEW, K.M.; HARIHARAN, M. Micropropagation of Kaempferia galanga L.: a medicinal plant. Plant Cell, Tissue and Organ Culture, v.28, p.229-230, 1992.

YASUDA, K.; TSUDA, T.; SHIMIZU, H.; SUGAYA, A. Multiplication of Curcuma species by tissue culture. Planta Medica, v.54, p.75-79, 1988.

YOSHIOKA, T.; FUJII, E.; ENDO, M.; WADA, K.; TOKUNAGA, Y.; SHIBA, N.; HOHSHO, H.; SHIBUYA, H.; MURAKI, T. Antiinflammatory potency of dehydrocuridione, a zedoaryderived sesquiterpene. Inflammatory Research, v.47, p.476-481, 1998.

Recebido em 23.11.99 